\title{
Reproductive Phenology of Hong Kong Shrubland
}

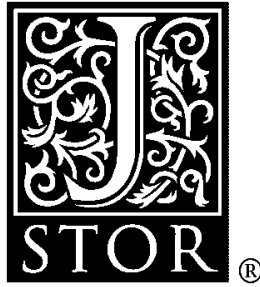

\author{
Richard T. Corlett
}

Journal of Tropical Ecology, Vol. 9, No. 4. (Nov., 1993), pp. 501-510.

Stable URL:

http://links.jstor.org/sici?sici=0266-4674\%28199311\%299\%3A4\%3C501\%3ARPOHKS\%3E2.0.CO\%3B2-P

Journal of Tropical Ecology is currently published by Cambridge University Press.

Your use of the JSTOR archive indicates your acceptance of JSTOR's Terms and Conditions of Use, available at

http://www.jstor.org/about/terms.html. JSTOR's Terms and Conditions of Use provides, in part, that unless you have obtained prior permission, you may not download an entire issue of a journal or multiple copies of articles, and you may use content in the JSTOR archive only for your personal, non-commercial use.

Please contact the publisher regarding any further use of this work. Publisher contact information may be obtained at http://www.jstor.org/journals/cup.html.

Each copy of any part of a JSTOR transmission must contain the same copyright notice that appears on the screen or printed page of such transmission.

JSTOR is an independent not-for-profit organization dedicated to and preserving a digital archive of scholarly journals. For more information regarding JSTOR, please contact support@jstor.org. 


\title{
Reproductive phenology of Hong Kong shrubland
}

\author{
RICHARD T. CORLETT
}

Department of Botany, University of Hong Kong, Pokfulam Road, Hong Kong

\begin{abstract}
Hong Kong is on the northern edge of the tropics and near the boundary of the Paleotropical and Holarctic floral kingdoms. The phenological states of 105 plant species in secondary shrubland were recorded weekly for three years. Community patterns of reproductive phenology are highly seasonal and vary little between years. There is a flowering maximum in May and a fruiting maximum in December/January. The winter fruiting peak coincides with diet switching by resident omnivorous birds and the arrival of partially frugivorous migrants from the Eastern Palearctic. However, wind-dispersed species also have a fruiting maximum at the same time, suggesting that fruiting in winter has other advantages.
\end{abstract}

KEY WORDS: bird migration, China, flowering, fruiting, Hong Kong, phenology, shrubland.

\section{INTRODUGTION}

Before the human disturbance of the last few thousand years, the subtropical lowlands of South China would have been covered by continuous broad-leaved evergreen or semi-evergreen forest. Very little of this forest now remains. All non-urban flat land is used for crops, while hillsides are largely uncultivated and covered in secondary grassland and shrubland, maintained by fire or by repeated harvesting of grass, ferns and shrubs for domestic fuel. Remnants of the original vegetation are, in most places, confined to damp ravines and other sites with natural protection from fire and cutting.

Hong Kong $\left(22^{\circ} 17^{\prime} \mathrm{N}, 114^{\circ} 09^{\prime} \mathrm{E}\right)$ lies in the southern part of this region (Figure 1) and has a climate and flora with both tropical and subtropical characteristics. Both rainfall and temperature are seasonal (Figure 2) but there has been no frost at sea-level since 1893 (Corlett 1992a) and the coincidence of dry and cool weather reduces the degree of water stress suffered by plants. Most woody species are evergreen. Takhtajan (1986) places the boundary between the Holarctic and Paleotropical Floral Kingdoms a few kilometres west of Hong Kong.

Hong Kong's 5.8 million human population is concentrated on the limited natural flat land, extended by coastal reclamation. More than $40 \%$ of the territory is protected in Country Parks, which consist largely of steep and rugged 


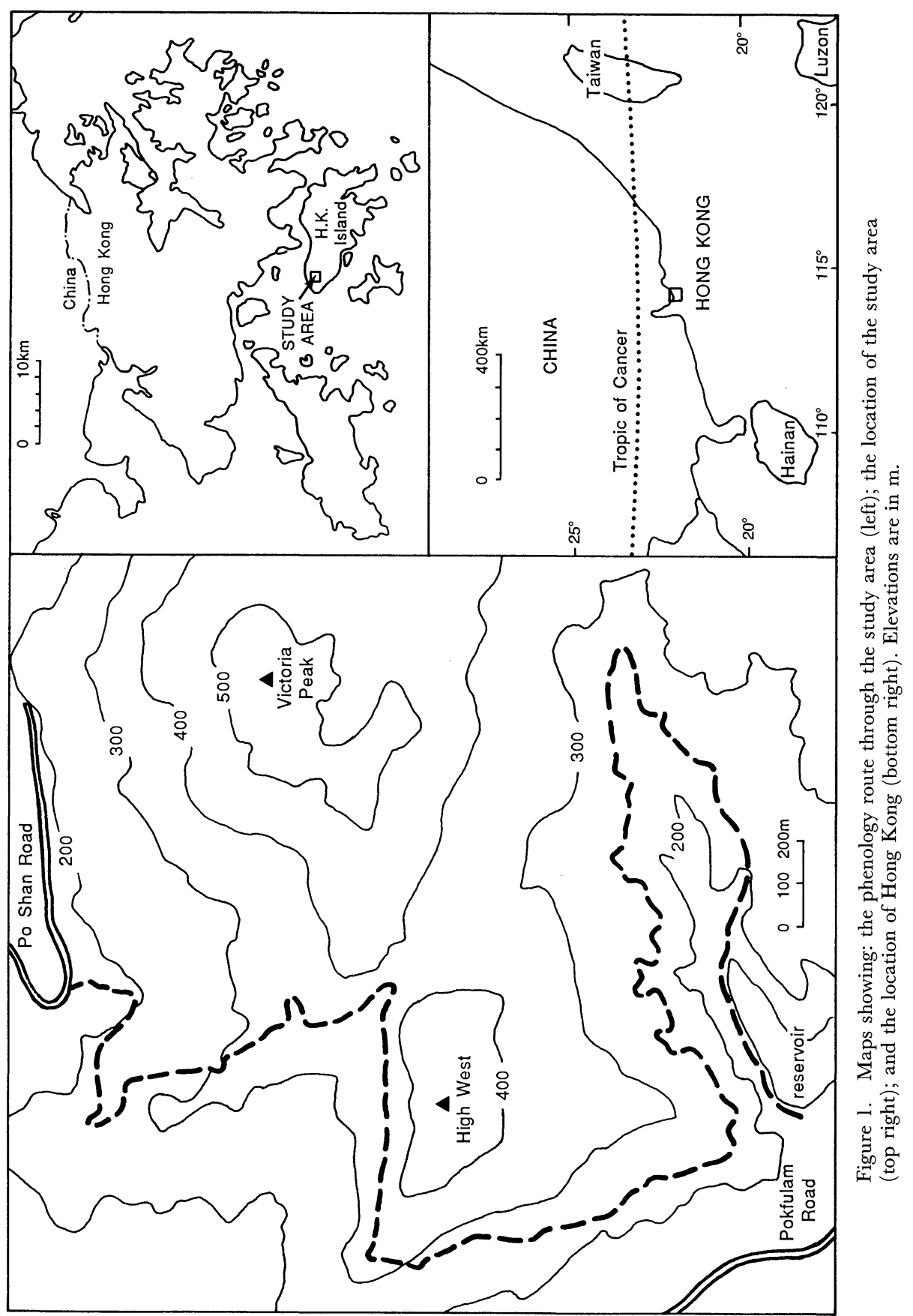


hills. Harvesting of biomass for fuel is no longer significant in Hong Kong but frequent hill fires have limited forest succession in most areas. My study area (Figure 1) has had no extensive fires for at least a decade and is now occupied by a mosaic of vegetation types forming a floristic and successional continuum from pure grassland to closed secondary forest, $10-15 \mathrm{~m}$ in height. The most extensive communities are species-rich shrublands, $1-1.25 \mathrm{~m}$ in height, and shrubby grasslands. Since the floras of the grassland and secondary forest stages are also present as minor components of the shrubland, I will refer to the entire floristic continuum as 'shrubland'.

Shrubland communities similar to those in the study area cover vast areas of South China. They are the major habitat of the region's surviving wildlife and of great importance to passage migrant and overwintering birds. Despite this, very little is known about their basic ecology. This study forms part of a long-term study of the dynamics of hillside communities in Hong Kong and South China.

\section{METHODS}

From July 1988 until June 1991 (omitting July-September 1990) the phenological states of the commonest 102 woody species along a $5.8 \mathrm{~km}$ route through the study area (Figure 1) were recorded at weekly intervals. All the species studied appear to be pollinated by insects and $86 \%$ (88 spp) are known or suspected to be dispersed by birds. Four species (Artocarpus hypargyreus, Diospyros morrisiana, Garcinia oblongifolia and Gnetum montanum) seem to be largely or entirely dispersed by mammals (civets and/or rhesus macaques) and the remaining ten are dispersed by wind. Because of my interest in food-availability to frugivorous birds, the three herbaceous species with fleshy fruits (Cassytha filiformis, Liriope spicata, Pothos chinensis) were also included in the study. An additional 34 woody species were included for the final year of observations (1990-1991) so that the total species list (Appendix, where authorities are given) represents more than $99 \%$ of the woody biomass in the study area. Data from these additional species are only used qualitatively here.

For each species, the population-level intensity of each phenological event (flowering, fruiting, leaf senescence and fall, leaf flushing) was described as increasing, the same, or decreasing, in comparison with the previous week. More detailed supporting notes were made where necessary. The high degree of intra-population synchronization of phenological events in almost all species and my familiarity with the flora and the route made this approach very efficient. The alternative, of following the phenological state of individual plants, would have severely limited the number of species that could be studied. Only the reproductive phenology is reported here and the phenological categories recorded for each species are reduced to presence or absence of flowers and ripe fruits. 
Community patterns of flowering and fruiting (for 105 species) are shown in Figure 2. Both are highly seasonal, with flowering peaking in May and fruiting in December/January. The maximum number of species in fruit is higher than the maximum number in flower because most species have a longer fruiting than flowering period. The fruiting peak for wind-dispersed species is a little earlier than for animal-dispersed species. There is remarkably little variation between years, despite significant differences in weather, most noticeably the mild winter and dry early summer of $1990 / 91$. All the woody species recorded along the phenology route flowered at least once during the three years but Canthium dicoccum did not fruit until July 1991, after the end of the study period. Litsea cubeba and Phyllanthus emblica were represented only by male plants on the phenology route. Most species flowered and fruited every year but Machilus cf. thunbergii did not flower in 1988 and Rapanea neriifolia flowered but did not fruit in 1989. Between-year differences in the timing of the flowering maxima for all species were always less than three weeks. Fruiting maxima were often less well defined and partly dependent on removal rates but between year differences were also minor.

Three species (Glochidion wrightii, Homalium cochinchinense and Lasianthus chinensis) flowered twice per year but they produced few or no fruits from the second episode. In the dioecious Ficus variolosa, female plants had two, distinct, synchronized crops of figs per year but the phenology of the male plants was too complex to describe without marking individual plants. No species flowered continuously but Breynia fruticosa flowered for the 10 warmer months of the year, although it fruited only sparsely and irregularly. Cassytha filiformis and Baeckia frutescens flowered for 7 and 6 months, respectively, and fruited for similar periods. Ormosia emarginata (which produces bright red seeds, offering no reward and apparently dispersed by deceit) had a brief flowering period but retained ripe seeds throughout the year.

Fruit development periods (estimated as the time between the start of the flowering maximum and the start of the fruiting maximum) for the 105 species ranged from 45 days (Lasianthus chinensis) to 365 days (Eurya nitida), with a mean of 178 days. The time between the annual community flowering and fruiting peaks (235 days) is greater than this mean fruit development period because species that flower before the May flowering peak tend to have longer development times than those that flower after the peak. Two extreme patterns can be recognized: species that flower one winter and fruit the next (e.g. Acer reticulatum, Enkianthus quinqueflorus, Eurya spp, Gordonia axillaris, Maesa spp, Rhododendron spp) and species that both flower and complete fruit development in one summer (e.g. Artocarpus hypargyreus, Garcinia oblongifolia, Gnetum montanum, Morinda umbellata, Phoenix hanceana). No species on the phenology route flowers one summer and fruits the next and only one species (Schefflera octophylla) flowers and fruits the same winter. 

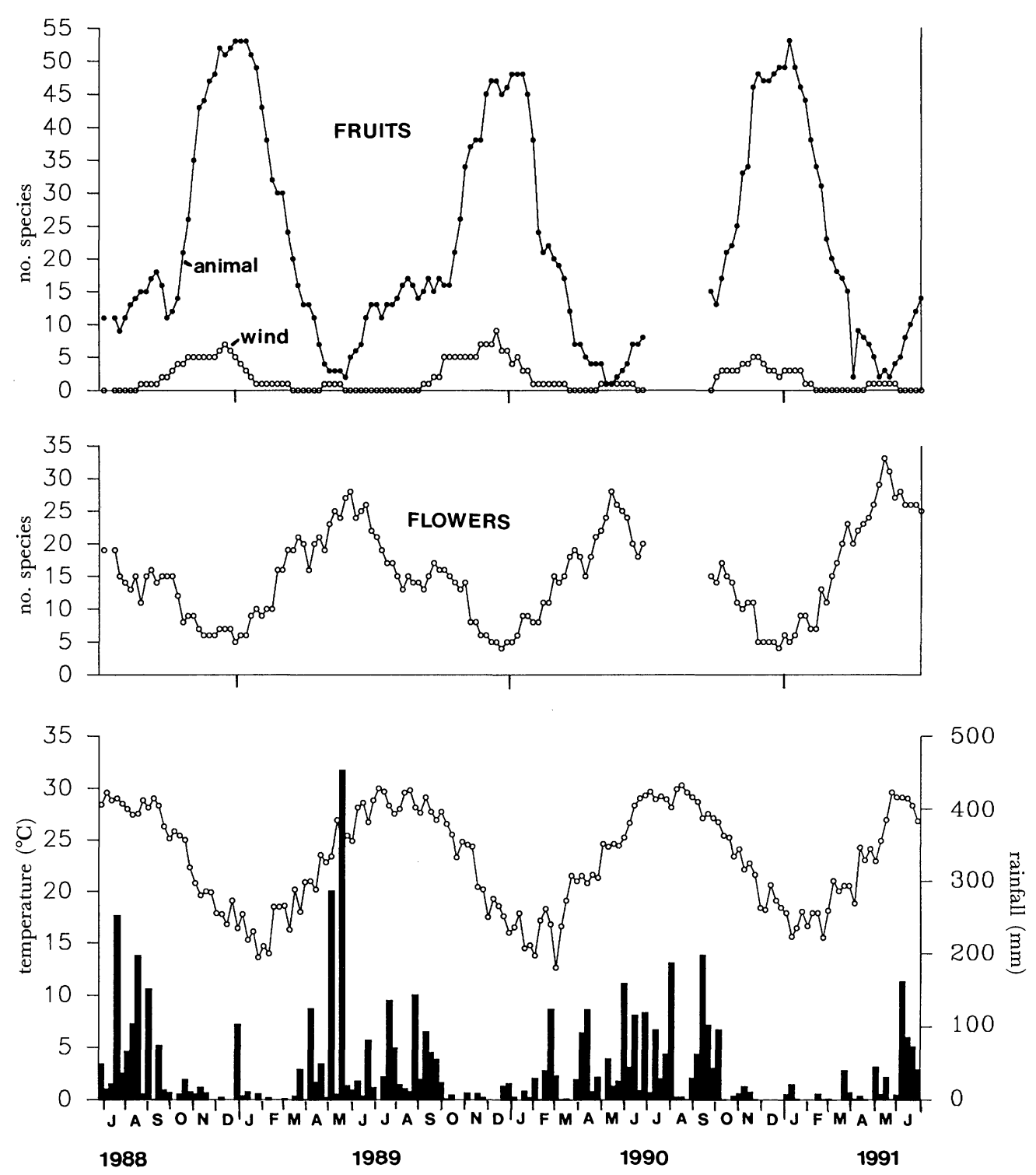

Figure 2. Weekly records of number of species in fruit (top: animal and wind-dispersed species separately) and in flower (middle) along a $5.8 \mathrm{~km}$ route. Mean temperature and total rainfall for the week preceding the observation day (bottom).

Congeneric species typically have overlapping flowering and fruiting times (68\% of the multispecies genera studied) but there are some striking exceptions. All six Ilex species have overlapping flowering periods between March and May but, while five species ripen fruit 220-280 days later during the community fruiting peak, Ilex asprella fruits in June, only 70 days after flowering. Other genera with a wide range of fruit development periods are Dalbergia (2 spp, 51- 
300 days), Smilax (3 spp, 81-224 days) and Zanthoxylum (3 spp, 132-280 days). In contrast, congeneric species in Litsea (3 spp) and Machilus (3 spp) - both in the Lauraceae - have very similar fruit development periods but no overlap in either flowering or fruiting times.

\section{DISGUSSION}

It can be argued that phenological data in the form of number of species in flower and fruit is of limited ecological value because no account is taken of the relative abundance of different species or their relative importance to floral visitors and frugivores (Blake et al. 1990). However, quantitative data on fruit or floral resources available per unit area are not only far more difficult to obtain but are also very sensitive to the species composition of the vegetation. In a patchy, anthropogenic landscape like Hong Kong's, the quantitative seasonal pattern of flower and fruit production varies greatly in space and has certainly also changed with the varying human impact over the last few millennia. Moreover, all major frugivores and, probably, many flower visitors have ranges which include many patches in which they forage very selectively. Resource availability would have to be assessed individually for each species: an impossible task given our current knowledge of the fauna. The patterns presented here, in contrast, are a property of the flora and unlikely to change significantly had the number of species sampled been increased. The flowering and fruiting patterns approximate the resource availability for wide-ranging generalist nectarivores and frugivores, such as honey-bees, and the major frugivorous birds and mammals.

The most striking feature of the community reproductive phenology of Hong Kong shrubland is its strong and predictable seasonality, despite the absence of climatic extremes. A similar pattern, with a March-June flowering maximum and a November-December fruiting maximum, was shown by 60, mostly woody, species at Ding Hu Shan Biosphere Reserve, $190 \mathrm{~km}$ WNW of Hong Kong (Li \& Wang 1984). This contrasts with the irregular, supra-annual reproductive peaks of equatorial Southeast Asia (Corlett 1990).

A flowering maximum between April and July is typical of plant communities in the seasonal northern hemisphere. At higher latitudes, flowering times are presumably constrained by the problems of flower production and/or pollination in winter and, possibly, the time needed to ripen fruits before the next winter limits the disperser fauna. It is not obvious why the same pattern should occur in Hong Kong, where mild winters permit flowering and insect pollination in several species and the fruit maximum is in winter. The sharpness of the flowering peak suggests a major advantage in flowering at this time, perhaps the number and activity of pollinators, although $I$ have no independent evidence for this. A consequence of this timing is that the majority of species bear unripe fruit throughout the hottest and wettest time of the year, when risks of predation or microbial damage would presumably be maximum. 
Unlike the May community flowering peak, a midwinter (and mid-dry season) fruiting maximum is unusual. In the seasonal tropics the fruiting maximum is typically during the wet season (Murphy \& Lugo 1986, Rathcke \& Lacey 1985) while at higher latitudes it is in autumn or late summer (Skeate 1987, Stiles 1980). In fact, it appears that few areas in the northern hemisphere have much fruit available in midwinter. Exceptions reported in the literature are the Mediterranean region (Herrera 1984) and northern Florida (Skeate 1987). The winter fruiting peak in both areas is of major significance to passage migrant and overwintering passerines while resident frugivores are of little importance. Hong Kong is also visited by numerous passerines from the Eastern Palearctic in winter (Chalmers 1986) but many resident birds are also at least seasonally frugivorous (Corlett 1992b). The most common resident frugivores are also the most common resident birds on Hong Kong hillsides: two species of bulbuls (Pycnonotus jocosus and P. sinensis) and the White-eye (Zosterops japonicus). All three species eat fruit and insects in summer but largely fruit in winter. Their populations are apparently swollen in winter by an influx of individuals from the north. Between November and March, they are joined by Palearctic species which include varying proportions of fruit in their diets (Corlett 1992b). The winter fruiting maximum could therefore be seen as an adaptation to seasonal diet switching in resident birds and frugivory by Palearctic migrants: both, in turn, probably influenced by a winter low in insect abundance and activity. That this is not the entire explanation, however, is shown by the occurrence of an almost simultaneous peak in fruiting by winddispersed species. This suggests that there are other advantages in winter fruiting which are independent of the mode of dispersal. Seeds dispersed in December or January must usually wait until April or May before reliable rains permit germination, so the nature of this advantage is not obvious.

While the evolutionary impact of migrant birds on fruiting phenology may have been lessened by the year-round presence of resident frugivores, the impact of the winter fruiting peak on the migratory behaviour of Palearctic omnivores has probably been much more significant. Most Palearctic insectivores are passage migrants in Hong Kong but those species which eat at least some fruit mainly robins and thrushes - are mostly winter residents. The shrublands of South China are probably the major overwintering area for such birds from the Eastern Palearctic.

\section{A G KNOWLEDGEMENTS}

I wish to thank S. T. Chan for introducing me to the flora of Hong Kong, D. Dudgeon for many useful suggestions, and D. A. Griffiths for his continued support and encouragement. 


\section{LITERATURE GITED}

BLAKE, J. G., LOISELlE, B. A., MOERMOND, T. C., LEVEY, D. J. \& DENSLOW, J. S. 1990. Quantifying abundance of fruits for birds in tropical habitats. Studies in Avian Biology 13:73-79.

CHALMERS, M. L. 1986. Annotated checklist of the birds of Hong Kong. 4th edition. Hong Kong Bird Watching Society, Hong Kong. 279 pp.

CORLETT, R. T. 1990. Flora and reproductive phenology of the rain forest at Bukit Timah, Singapore. Journal of Tropical Ecology 6:55-63.

CORLETT, R: T. 1992a. The impact of cold and frost on terrestrial vegetation in Hong Kong. Memoirs of the Hong Kong Natural History Society 19:133-135.

CORLETT, R. T. 1992b. Seed dispersal by birds in Hong Kong shrubland. Memoirs of the Hong Kong Natural History Society 19:129-130.

HERRERA, C. M. 1984. A study of avian frugivores, bird-dispersed plants, and their interaction in Mediterranean scrubland. Ecological Monographs 54(1):1-23.

LI, M. J. \& WANG, Z. H. 1984. The phenology of common plants in Ding Hu Shan (in Chinese). Tropical and Subtropical Forest Ecosystems 2:1-11.

MURPHY, P. G. \& LUGO, A. E. 1986. Ecology of tropical dry forest. Annual Review of Ecology and Systematics 17:67-88.

RATHCKE, B. \& LACEY, E. P. 1985. Phenological patterns of terrestrial plants. Annual Review of Ecology and Systematics 16:179-214.

SKEATE, S. T. 1987. Interactions beteeen birds and fruits in a northern Florida hammock community. Ecology 68(2): 297-309.

STILES, E. W. 1980. Patterns of fruit presentation and seed dispersal in bird-disseminated woody plants in eastern deciduous forest. American Naturalist 116:670-688.

TAKHTAJAN, A. L. 1986. Floristic regions of the world. University of California Press, USA.

\section{Accepted 26 May 1993}

\section{APPENDIX}

Species for which at least one year's phenological data was obtained. Those marked with an asterisk were observed for less than 3 years and are not included in Figure 2.

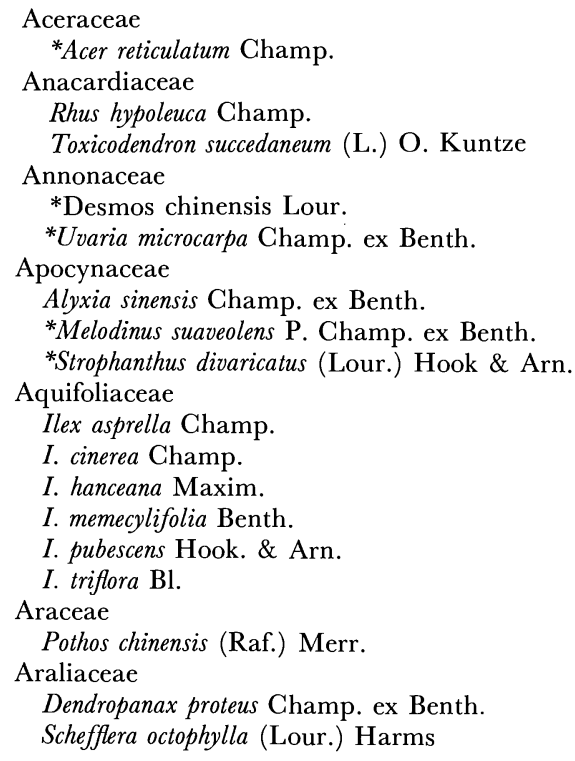

Asclepiadaceae

*Gymnema sylvestre (Retz.) Schult.

Caprifoliaceae

Viburnum odoratissimum Ker Gawl.

*Lonicera longiflora (Lindl.) DC.

${ }^{*}$ L. macrantha (D. Don) Spreng.

Celastraceae

Celastrus hindsii Benth.

Euonymus chinensis Lindl.

Chloranthaceae

Sarcandra glabra (Thunb.) Nakai

Daphniphyllaceae

Daphniphyllum calycinum Benth.

Ebenaceae

Diospyros morrisiana Hance

D. vaccinioides Lindl.

Elaeocarpaceae

Elaeocarpus chinensis (Gardn. \& Champ.) Benth.

E. sylvestris (Lour.) Poir.

Ericaceae

Enkianthus quinqueflorus Lour.

Euphorbiaceae

Antidesma japonicum S. \& Z.

A. microphyllum Hemsl.

Aporusa dioica (Roxb.) M.A.

*Breynia fruticosa Hook. f.

Bridelia tomentosa $\mathrm{Bl}$.

* Glochidion wrightii Benth.

Mallotus paniculatus (Lam.) Muell. Arg. 
*Phyllantus cochinchinensis Spreng.

*P. emblica $\mathrm{L}$.

Sapium discolor (Benth.) Muell.-Arg.

Fagaceae

${ }^{*}$ Quercus myrsinaefolia $\mathrm{B} 1$.

Flacourtiaceae

*Homalium cochinchinense (Lour.) Druce

* Scolopia saeva Hance

Gnetaceae

Gnetum montanum Markgr.

Grossulariaceae

Itea chinensis Hook. \& Arn.

Guttiferae

Cratoxylum cochinchinense (Lour.) B1.

Garcinia oblongifolia Champ. ex Benth.

Ixonanthaceae

*Ixonanthes chinensis Champ.

Lauraceae

Cassytha filiformis $\mathbf{L}$.

Cinnamomum camphora (L.) Presl.

*Cryptocarya chinensis (Hance) Hemsl.

Litsea cubeba (Lour.) Pers.

L. glutinosa (Lour.) C.B.Rob.

L. rotundifolia Hemsl.

Machilus breviflora (Benth.) Hemsl.

$M$. cf. thunbergii Sieb. \& Zucc.

$M$. velutina Champ. ex Benth.

Leguminosae

Dalbergia benthami Prain

D. hancei Benth.

${ }^{*} D$. millettii Benth.

* Millettia nitida Benth.

* Millettia speciosa Champ.

*Ormosia emarginata (Hook. \& Arn.) Benth.

Liliaceae

*Asparagus cochinchinensis (Lour.) Merr.

Dianella ensifolia (L.) DC.

Liriope spicata Lour.

Melastomataceae

Melastoma candidum D. Don

* M. dodecandrum Lour.

M. sanguineum Sims

Menispermaceae

Hypserpa nitida Miers

Moraceae

Artocarpus hypargyreus Hance ex Benth.

*Ficus variolosa Lindl. ex Benth.

Myrsinaceae

Ardisia crenata Sims

A. punctata Lindl.

A. quinquegona $\mathrm{Bl}$.

Embelia laeta (L.) Mez

E. ribes Burm. f.

Maesa japonica (Thunb.) Mor. \& Zoll.

$M$. perlarius (Lour.) Merr.

Rapanea neriifolia (S. \& Z.) Mez

Myrtaceae

Baeckea frutescens $\mathrm{L}$.

Rhodomyrtus tomentosa (Ait.) Hassk.

Syzygium buxifolium Hk. \& Arn.

Oleaceae

Jasminum lanceolarium Roxb.

Ligustrum sinense Lour.
Palmae

Phoenix hanceana Naud.

Pentaphylacaceae

Pentaphylax euryoides Gardn. \& Champ.

Pittosporaceae

Pittosporum glabratum Lindl.

Ranunculaceae

Clematis uncinata Champ.

Rhamnaceae

Berchemia racemosa Sieb. \& Zucc.

Sageretia theezans (L.) Brongn.

Rosaceae

Photinia prunifolia (Hook. \& Arn.) Lindl.

Rhaphiolepis indica (L.) Lindl.

Rubus reflexus Ker

Rubiaceae

Antirhea chinensis Hook. $\mathrm{f}$.

Canthium dicoccum (Gaertn.) Merr.

Diplospora dubia (Lindley) Masamune

Gardenia jasminoides Ellis

*Hedyotis acutangula Champ.

Lasianthus chinensis Benth.

Morinda umbellata L.

Mussaenda pubescens Ait. f.

Paederia scandens (Lour.) Merr.

Psychotria rubra (Lour.) Poir.

P. serpens L.

Rutaceae

Acronychia pedunculata (L.) Miq.

Evodia lepta (Spr.) Merr.

Toddalia asiatica (L.) Lam.

Zanthoxylum avicennae (Lam.) DC.

Z. nitidum (Roxb.) DC.

$Z$. scandens $\mathrm{Bl}$.

Santalaceae

Dendrotrophe frutescens (Benth.) Danser

Simaroubaceae

*Picrasma quassioides (D. Don) Benn.

Smilacaceae

Heterosmilax gaudichaudiana (Kunth.) Max.

Smilax china $\mathrm{L}$.

*S. corbularia Kunth.

S. glabra Roxb.

S. lancifolia Roxb.

Staphyleaceae

Turpinia arguta Seem.

*T. cochinchinensis (Lour.) Merr.

Sterculiaceae

*Helicteres angustifolia L.

Reevesia thyrsoidea Lindl.

Sterculia lanceolata Cav.

Styracaceae

*Styrax odoratissimus Champ.

S. suberifolia Hook. \& Arn.

Symplocaceae

*Symplocos congesta Benth.

S. crassifolia Benth.

Theaceae

*Eurya chinensis R. Brown

E. macartneyi Champ.

E. nitida Korth.

Gordonia axillaris (Don) Dietr.

*Schima superba Gardn. \& Champ. 
Ternstroemia gymnanthera (W. \& A.) Sprague Thymelaeaceae

*Wikstroemia indica (L.) C. A. Mey W. nutans Champ.

\section{Ulmaceae}

Celtis sinensis Pers.

\section{Urticaceae}

*Boehmeria densiflora Hook. \& Arn.

\section{Verbenaceae}

Clerodendrum fortunatum $\mathrm{L}$.

Vitaceae

Cayratia corniculata (Benth.) Gagnep.

Zingiberaceae

Alpinia stachyodes Hance 